\title{
Vilsmeier Haack Adducts as Effective Reagents for Regioselective Nitration of Aromatic Compounds under Conventional and Non-Conventional Conditions
}

\author{
Kamatala Chinna Rajanna*, Mukka Satish Kumar, Purugula Venkanna, \\ Soma Ramgopal, Marri Venkateswarlu \\ Department of Chemistry, Osmania University, Hyderabad, India \\ E-mail: kcrajannaou@yahoo.com \\ Received September 3, 2011; revise October 9, 2011; accepted October 17, 2011
}

\begin{abstract}
Nitration of aromatic Compounds is triggered by Vilsmeier-Haack reagent (DMF/POCl $)_{3}$ or $\left(\mathrm{DMF} / \mathrm{SOCl}_{2}\right)$ in the presence of $\mathrm{KNO}_{3}$ or $\mathrm{NaNO}_{2}$ under conventional and non-conventional conditions. The reactions afforded corresponding Nitro derivatives in very good yield with high regioselectivity. The results obtained in non-conventional methods (Micro wave irradiation, Grinding, Sonication) are comparable with those obtained under conventional conditions, but the reaction times of former conditions are substantially shorter than that of the latter.
\end{abstract}

Keywords: Nitration, $\mathrm{KNO}_{3}$ or $\mathrm{NaNO}_{2}$, Vilsmeier-Haack Reagent, Microwave Irradiation (MWI), Grinding, Sonication

\section{Introduction}

Over the years, Nitration of aromatic compounds has been an area of interest to chemists because Nitro arenes are useful intermediates in the synthesis of organometallic species and pharmaceutically important compounds [1-3]. Direct methods of Nitration of aromatic compounds involve the use of hazardous acid mixture $\left(\mathrm{HNO}_{3}\right.$ and $\mathrm{H}_{2} \mathrm{SO}_{4}$ ) that is highly toxic, corrosive, and pollutes to the environment, and metal ion catalysts are generally expensive. In view of this, there has been an upsurge in the design and execution of mild methods of Nitration of aromatic compounds [4-17]. Over the past decade, our group has also been actively involved in designing a variety of eco friendly materials using micelle-forming surfactants as catalysts and unconventional energy sources (such as microwave irradiation and ultrasound) to assist Vilsmeier-Haack (VH) reactions [18-20] and Hunsdiecker reactions [21-22] Dramatic rate accelerations followed by an increase in the product yield were observed in these reactions in all cases. Organic reactions performed under solvent-free conditions have gained much attention because of their enhanced selectivity, mild reaction conditions, and associated ease of manipulation. The recent reviews and publications in this field prove the im- portance of solvent-free organic synthesis [23-28] and highlights that this process is not only simple but also satisfies both economical and environmental demands by replacing the toxic solvents.

\section{Results and Discussion}

The VH reaction [29-32] is widely used for formylation. It can be applied to introduce an acetyl group on activated aromatic or hetero aromatic compounds, many other conversions can be achieved with this technology. It is one of the most versatile reactions in organic synthesis for the conversion of arenes to corresponding bromo derivatives. In general, $\left(\mathrm{DMF} / \mathrm{POCl}_{3}\right)$ or $\left(\mathrm{DMF} / \mathrm{SOCl}_{2}\right)$ are used to generate an iminium salt intermediate salt can be used in the synthesis of a large number of heterocyclic compounds. The $\mathrm{VH}$ reaction is a mild method known for the introduction of a formyl (-CHO) group to various activated aromatic and hetero aromatic compounds. Recently our group reported that Vilsmeier-Haack (VH) reagents could be effectively used in presence of $\mathrm{KBr}$ or NBS for bromination of arenes [20]. Encouraged by this result, we tried to use $\mathrm{VH}$ reagent $\left(\mathrm{DMF} / \mathrm{SOCl}_{2}\right.$ and DMF/ $\mathrm{POCl}_{3}$ ) in presence of $\mathrm{KNO}_{3}$ and $\mathrm{NaNO}_{2}$ for nitration reactions. Aromatic compounds such as phenols 
and amines underwent nitration treated with $\mathrm{VH}$ reagent $\left(\mathrm{DMF} / \mathrm{SOCl}_{2}\right.$ and $\mathrm{DMF} / \mathrm{POCl}_{3}$ ) in presence of $\mathrm{KNO}_{3}$ and $\mathrm{NaNO}_{2}$ afforded good yields of products under stirred conditions at room temperature. In this study $\mathrm{KNO}_{3}$ and $\mathrm{NaNO}_{2}$ were used as reagents for the generation of nitronium ions. Under these conditions only nitro derivatives were obtained. Howwever, in the absence of $\mathrm{KNO}_{3}$ and $\mathrm{NaNO}_{2}$ formylated products could be obtained. We have analysed the products carefully to check this point. To check the generality of the reaction an array of aromatic compounds were used as substrates as shown in Scheme 1.

An important note that, Nitration of aniline using ( $\mathrm{HNO}_{3}$ and $\mathrm{H}_{2} \mathrm{SO}_{4}$ ) forms m-nitro aniline as major product, it is because aniline is a strong activating group forms anlilinium salt $\left(\mathrm{C}_{6} \mathrm{H}_{5}-\mathrm{NH}_{3}^{+}\right)$with strong acid. But, using VHR and $\mathrm{KNO}_{3}$ or $\mathrm{NaNO}_{2}$ can afford o, p-nitro anilines as major products.

The reaction rapidly afforded high yields of the corresponding Nitro derivatives. All the products were characterized by physical data (m.p/b.p), ${ }^{1} \mathrm{H}$ NMR, and mass

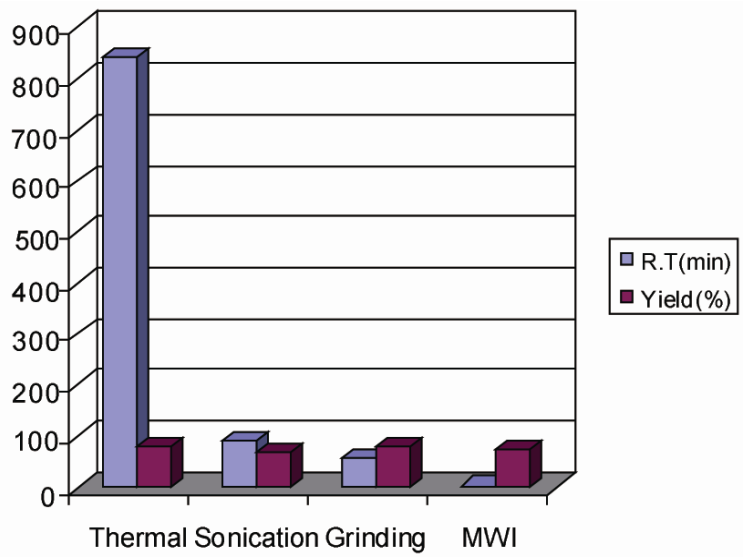

Figure 1. Nitration of Aromatic Compounds with VH reagent $\left(\mathrm{DMF}+\mathrm{SOCl}_{2}\right)$ and $\mathrm{KNO}_{3}$.

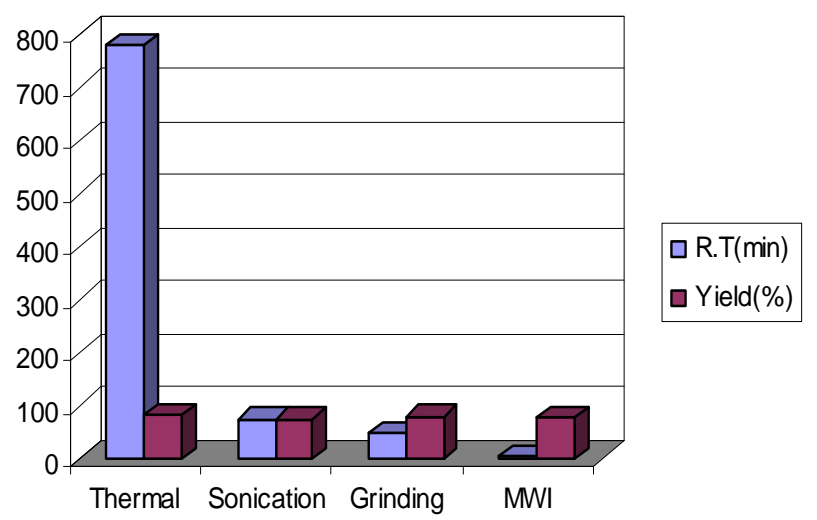

Figure 3. Nitration of Aromatic Compounds with VH reagent $\left(\mathrm{DMF}+\mathrm{POCl}_{3}\right)$ and $\mathrm{KNO}_{3}$. spectra, with authentic samples and found to be satisfactory. To compare these results, aromatic compounds were treated with $\mathrm{VH}$ adduct $\left(\mathrm{POCl}_{3}+\mathrm{DMF}\right)$ in Acetonitrile under reflux conditions. When aromatic amines and Phenols were reacted with $\left(\mathrm{POCl}_{3}+\mathrm{DMF}\right)$ in the presence of $\mathrm{KNO}_{3}$ or $\mathrm{NaNO}_{2}$, the reaction indicated corresponding Nitro derivatives. The reaction proceeded rapidly with $\left(\mathrm{POCl}_{3}+\mathrm{DMF}\right) /\left(\mathrm{KNO}_{3}\right.$ or $\left.\mathrm{NaNO}_{2}\right)$ over $\left(\mathrm{SOCl}_{2}+\mathrm{DMF}\right) /$ $\left(\mathrm{KNO}_{3}\right.$ or $\left.\mathrm{NaNO}_{2}\right)$ to afford high yields of the corresponding Nitro derivatives. Data summarized in Figures 1-4 and Tables 1 and 2. Figures 1-4 clearly demon-

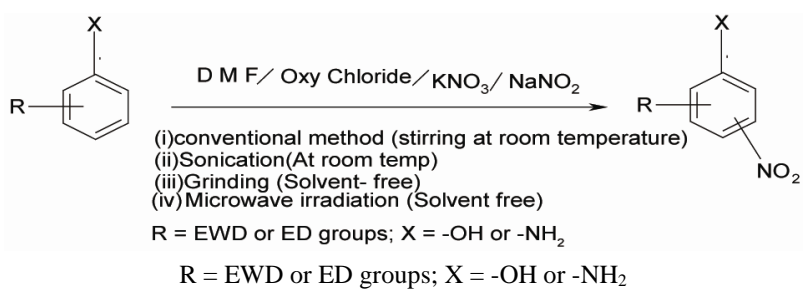

Scheme 1. Nitration of aromatic compounds with $\mathrm{VH}$ reagents and $\mathrm{KNO}_{3} / \mathrm{NaNO}_{2}$ under conventional and non-conventional conditions.

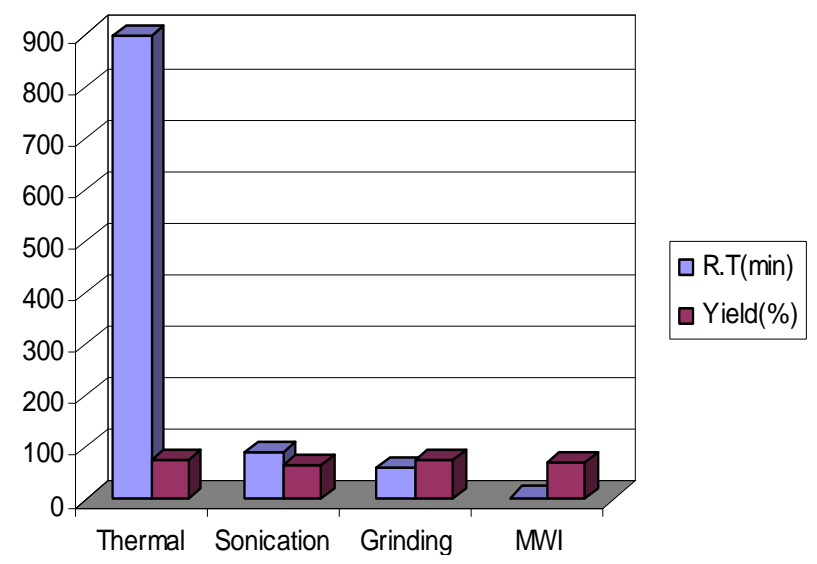

Figure 2. Nitration of Aromatic Compounds with VH reagent $\left(\mathrm{DMF}+\mathrm{SOCl}_{2}\right)$ and $\mathrm{NaNO}_{2}$.

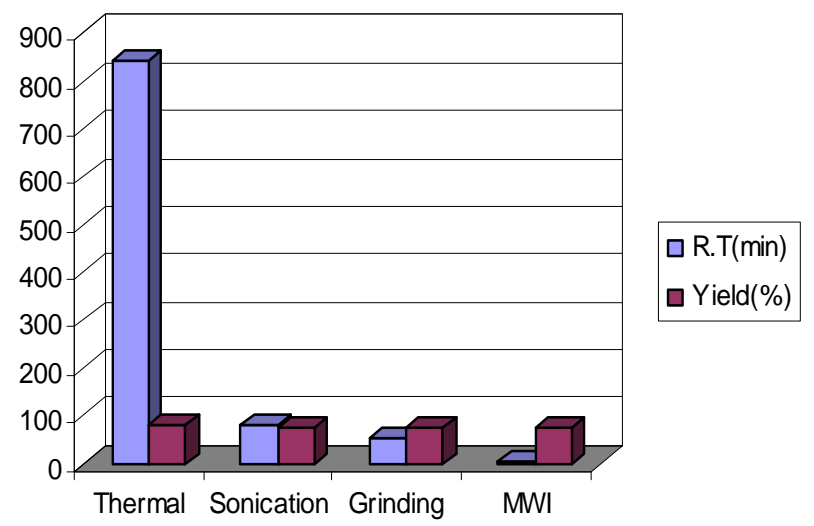

Figure 4. Nitration of Aromatic Compounds with VH reagent $\left(\mathrm{DMF}+\mathrm{POCl}_{3}\right)$ and $\mathrm{NaNO}_{2}$. 
Table 1. Nitration of certain aromatic compounds under Vilsmeier Haack Conditions.

\begin{tabular}{|c|c|c|c|c|c|c|c|c|c|c|c|c|c|c|c|c|c|}
\hline \multirow{3}{*}{ Entry } & \multirow{3}{*}{ Substrate } & \multicolumn{4}{|c|}{$\begin{array}{c}\text { Thermal } \\
\text { (Room temp) }\end{array}$} & \multicolumn{4}{|c|}{$\begin{array}{l}\text { Sonication } \\
\text { (Room temp) }\end{array}$} & \multicolumn{4}{|c|}{$\begin{array}{c}\text { Grinding } \\
\text { (Solvent free) }\end{array}$} & \multicolumn{4}{|c|}{$\begin{array}{l}\text { Microwave (300 watt) } \\
\text { (Solvent free) }\end{array}$} \\
\hline & & \multicolumn{2}{|c|}{$\mathrm{KNO}_{3}$} & \multicolumn{2}{|c|}{$\mathrm{NaNO}_{2}$} & \multicolumn{2}{|c|}{$\mathrm{KNO}_{3}$} & \multicolumn{2}{|c|}{$\mathrm{NaNO}_{2}$} & \multicolumn{2}{|c|}{$\mathrm{KNO}_{3}$} & \multicolumn{2}{|c|}{$\mathrm{NaNO}_{2}$} & \multicolumn{2}{|c|}{$\mathrm{KNO}_{3}$} & \multicolumn{2}{|c|}{$\mathrm{NaNO}_{2}$} \\
\hline & & $\begin{array}{l}\text { R.T } \\
\text { (h) }\end{array}$ & $\begin{array}{l}\text { Yield } \\
(\%)\end{array}$ & $\begin{array}{l}\text { R.T } \\
\text { (h) }\end{array}$ & $\begin{array}{l}\text { Yield } \\
(\%)\end{array}$ & $\begin{array}{l}\text { R.T } \\
\text { min }\end{array}$ & $\begin{array}{l}\text { Yield } \\
(\%)\end{array}$ & $\begin{array}{l}\text { R.T } \\
\text { min }\end{array}$ & $\begin{array}{l}\text { Yield } \\
(\%)\end{array}$ & $\begin{array}{l}\text { R.T } \\
\text { min }\end{array}$ & $\begin{array}{l}\text { Yield } \\
(\%)\end{array}$ & $\begin{array}{l}\text { R.T } \\
\text { min }\end{array}$ & $\begin{array}{l}\text { Yield } \\
(\%)\end{array}$ & $\begin{array}{l}\text { R.T } \\
\text { (Sec) }\end{array}$ & $\begin{array}{l}\text { Yield } \\
(\%)\end{array}$ & $\begin{array}{l}\text { R.T } \\
\text { (Sec) }\end{array}$ & $\begin{array}{l}\text { Yield } \\
(\%)\end{array}$ \\
\hline 1 & Phenol & 14 & 78 & 15 & 74 & 90 & 70 & 90 & 66 & 60 & 80 & 60 & 74 & 240 & 74 & 250 & 70 \\
\hline 2 & o-Cresol & 14 & 82 & 15 & 76 & 90 & 76 & 90 & 72 & 60 & 82 & 60 & 75 & 210 & 76 & 230 & 72 \\
\hline 3 & p-Cresol & 14 & 80 & 15 & 74 & 90 & 75 & 90 & 72 & 60 & 80 & 60 & 75 & 220 & 75 & 230 & 70 \\
\hline 4 & m-Cresol & 14 & 76 & 15 & 72 & 90 & 70 & 90 & 65 & 60 & 75 & 60 & 70 & 240 & 72 & 240 & 68 \\
\hline 5 & o-Cl phenol & 14 & 80 & 14 & 75 & 90 & 74 & 90 & 68 & 60 & 80 & 60 & 74 & 240 & 72 & 260 & 70 \\
\hline 6 & $\begin{array}{c}\text { p-Cl } \\
\text { phenol }\end{array}$ & 14 & 75 & 15 & 72 & 90 & 72 & 90 & 65 & 60 & 76 & 60 & 74 & 240 & 70 & 260 & 68 \\
\hline 7 & p-Br phenol & 15 & 74 & 15 & 70 & 90 & 68 & 90 & 64 & 60 & 74 & 60 & 70 & 250 & 70 & 260 & 66 \\
\hline 8 & $\begin{array}{l}\text { o-OH benzal- } \\
\text { dehyde }\end{array}$ & 15 & 72 & 16 & 65 & 90 & 68 & 90 & 60 & 60 & 74 & 60 & 68 & 250 & 70 & 250 & 65 \\
\hline 9 & $\begin{array}{l}\text { p-OH benzal- } \\
\text { dehyde }\end{array}$ & 15 & 70 & 16 & 62 & 90 & 65 & 90 & 58 & 60 & 70 & 60 & 64 & 260 & 68 & 260 & 62 \\
\hline 10 & $\begin{array}{c}\text { o-OH } \\
\text { phenol (R) }\end{array}$ & 14 & 82 & 15 & 78 & 90 & 78 & 90 & 72 & 60 & 84 & 60 & 76 & 210 & 78 & 210 & 75 \\
\hline 11 & $\begin{array}{c}\mathrm{p}-\mathrm{OH} \\
\text { phenol (Q) }\end{array}$ & 14 & 80 & 15 & 75 & 90 & 75 & 90 & 70 & 60 & 80 & 60 & 75 & 210 & 76 & 210 & 72 \\
\hline 12 & $\alpha,-$ Napthol & 16 & 62 & 16 & 58 & 90 & 58 & 90 & 54 & 60 & 62 & 60 & 58 & 300 & 60 & 300 & 56 \\
\hline 13 & $\beta$-Napthol & 16 & 66 & 16 & 60 & 90 & 62 & 90 & 58 & 60 & 66 & 60 & 60 & 300 & 62 & 300 & 58 \\
\hline 14 & $\begin{array}{l}\text { 3-OH aceto- } \\
\text { phenone }\end{array}$ & 14 & 75 & 15 & 70 & 90 & 72 & 90 & 70 & 60 & 76 & 60 & 72 & 240 & 72 & 250 & 68 \\
\hline 15 & Aniline & 14 & 75 & 15 & 70 & 90 & 68 & 90 & 60 & 60 & 78 & 60 & 72 & 210 & 74 & 260 & 68 \\
\hline 16 & $\begin{array}{l}4-\mathrm{NH}_{2} \\
\text { phenol }\end{array}$ & 14 & 76 & 15 & 72 & 90 & 72 & 90 & 68 & 60 & 75 & 60 & 70 & 210 & 75 & 220 & 65 \\
\hline 17 & $\begin{array}{l}3-\mathrm{NH}_{2} \\
\text { phenol }\end{array}$ & 14 & 74 & 15 & 66 & 90 & 68 & 90 & 62 & 60 & 75 & 60 & 65 & 220 & 70 & 235 & 60 \\
\hline 18 & $\begin{array}{l}\text { m-Chloro } \\
\text { aniline }\end{array}$ & 16 & 68 & 16 & 60 & 90 & 64 & 90 & 56 & 60 & 66 & 60 & 60 & 260 & 64 & 270 & 60 \\
\hline 19 & p-Toluidine & 14 & 72 & 15 & 68 & 90 & 68 & 90 & 60 & 60 & 74 & 60 & 66 & 220 & 70 & 230 & 62 \\
\hline 20 & o-Toluidine & 14 & 74 & 15 & 70 & 90 & 70 & 90 & 60 & 60 & 75 & 60 & 68 & 220 & 70 & 230 & 64 \\
\hline
\end{tabular}

$\mathrm{VHR}=\left(\mathrm{DMF}+\mathrm{SOCl}_{2}\right) ;$ SOLVENT $=$ Acetonitrile. 
Table 2. Nitration of certain aromatic compounds under Vilsmeier Haack Conditions.

\begin{tabular}{|c|c|c|c|c|c|c|c|c|c|c|c|c|c|c|c|c|c|}
\hline \multirow{3}{*}{ Entry } & \multirow{3}{*}{ Substrate } & \multicolumn{4}{|c|}{$\begin{array}{c}\text { Thermal } \\
\text { (Room temp) }\end{array}$} & \multicolumn{4}{|c|}{$\begin{array}{l}\text { Sonication } \\
\text { (Room temp) }\end{array}$} & \multicolumn{4}{|c|}{$\begin{array}{c}\text { Grinding } \\
\text { (Solvent free) }\end{array}$} & \multicolumn{4}{|c|}{$\begin{array}{l}\text { Microwave (300 watt) } \\
\text { (Solvent free) }\end{array}$} \\
\hline & & \multicolumn{2}{|c|}{$\mathrm{KNO}_{3}$} & \multicolumn{2}{|c|}{$\mathrm{NaNO}_{2}$} & \multicolumn{2}{|c|}{$\mathrm{KNO}_{3}$} & \multicolumn{2}{|c|}{$\mathrm{NaNO}_{2}$} & \multicolumn{2}{|c|}{$\mathrm{KNO}_{3}$} & \multicolumn{2}{|c|}{$\mathrm{NaNO}_{2}$} & \multicolumn{2}{|c|}{$\mathrm{KNO}_{3}$} & \multicolumn{2}{|c|}{$\mathrm{NaNO}_{2}$} \\
\hline & & $\begin{array}{l}\text { R.T } \\
\text { (h) }\end{array}$ & $\begin{array}{l}\text { Yield } \\
(\%)\end{array}$ & $\begin{array}{l}\text { R.T } \\
\text { (h) }\end{array}$ & $\begin{array}{l}\text { Yield } \\
(\%)\end{array}$ & $\begin{array}{l}\text { R.T } \\
\text { min }\end{array}$ & $\begin{array}{l}\text { Yield } \\
(\%)\end{array}$ & $\begin{array}{l}\text { R.T } \\
\text { min }\end{array}$ & $\begin{array}{l}\text { Yield } \\
(\%)\end{array}$ & $\begin{array}{l}\text { R.T } \\
\text { min }\end{array}$ & $\begin{array}{l}\text { Yield } \\
(\%)\end{array}$ & $\begin{array}{l}\text { R.T } \\
\text { min }\end{array}$ & $\begin{array}{l}\text { Yield } \\
(\%)\end{array}$ & $\begin{array}{l}\text { R.T } \\
\text { (Sec) }\end{array}$ & $\begin{array}{l}\text { Yield } \\
(\%)\end{array}$ & $\begin{array}{l}\text { R.T } \\
\text { (Sec) }\end{array}$ & $\begin{array}{l}\text { Yield } \\
(\%)\end{array}$ \\
\hline 1 & Phenol & 13 & 82 & 14 & 78 & 75 & 75 & 80 & 72 & 50 & 82 & 50 & 76 & 220 & 78 & 230 & 72 \\
\hline 2 & o-Cresol & 13 & 84 & 14 & 80 & 75 & 80 & 80 & 76 & 50 & 85 & 50 & 80 & 210 & 80 & 220 & 76 \\
\hline 3 & p-Cresol & 13 & 80 & 14 & 75 & 75 & 76 & 80 & 72 & 50 & 82 & 50 & 76 & 210 & 78 & 210 & 70 \\
\hline 4 & m-Cresol & 13 & 78 & 14 & 72 & 75 & 76 & 80 & 70 & 50 & 80 & 50 & 72 & 230 & 76 & 230 & 70 \\
\hline 5 & o-Cl phenol & 15 & 82 & 15 & 76 & 75 & 74 & 80 & 72 & 50 & 84 & 50 & 76 & 220 & 76 & 240 & 72 \\
\hline 6 & p- Cl phenol & 13 & 78 & 14 & 75 & 75 & 75 & 80 & 72 & 50 & 80 & 50 & 76 & 220 & 74 & 240 & 70 \\
\hline 7 & p-Br phenol & 14 & 76 & 14 & 72 & 75 & 72 & 80 & 68 & 50 & 78 & 50 & 72 & 250 & 72 & 260 & 66 \\
\hline 8 & $\begin{array}{c}\text { o-OH } \\
\text { benzaldehyde }\end{array}$ & 14 & 75 & 15 & 70 & 75 & 72 & 80 & 66 & 50 & 78 & 50 & 70 & 240 & 72 & 240 & 66 \\
\hline 9 & $\begin{array}{c}\mathrm{p}-\mathrm{OH} \\
\text { benzaldehyde }\end{array}$ & 14 & 70 & 15 & 68 & 75 & 68 & 80 & 64 & 50 & 72 & 50 & 65 & 240 & 70 & 240 & 65 \\
\hline 10 & $\begin{array}{c}\text { o-OH } \\
\text { phenol (R) }\end{array}$ & 13 & 84 & 14 & 80 & 75 & 80 & 80 & 75 & 50 & 84 & 50 & 80 & 200 & 80 & 200 & 76 \\
\hline 11 & $\begin{array}{c}\text { p-OH } \\
\text { phenol (Q) }\end{array}$ & 13 & 82 & 14 & 78 & 75 & 78 & 80 & 72 & 50 & 80 & 50 & 76 & 200 & 76 & 200 & 72 \\
\hline 12 & $\alpha$, -Napthol & 15 & 64 & 15 & 60 & 75 & 60 & 80 & 54 & 50 & 65 & 50 & 58 & 280 & 62 & 280 & 58 \\
\hline 13 & $\beta$-Napthol & 15 & 60 & 15 & 58 & 75 & 56 & 80 & 52 & 50 & 66 & 50 & 60 & 280 & 64 & 280 & 60 \\
\hline 14 & $\begin{array}{c}\text { 3-OH } \\
\text { acetophenone }\end{array}$ & 13 & 78 & 14 & 70 & 75 & 75 & 80 & 72 & 50 & 76 & 50 & 74 & 240 & 75 & 250 & 70 \\
\hline 15 & Aniline & 13 & 78 & 14 & 72 & 75 & 70 & 80 & 60 & 50 & 76 & 50 & 72 & 230 & 74 & 250 & 65 \\
\hline 16 & 4- $\mathrm{NH}_{2}$ phenol & 13 & 78 & 14 & 74 & 75 & 72 & 80 & 68 & 50 & 78 & 50 & 75 & 200 & 75 & 220 & 68 \\
\hline 17 & 3- $\mathrm{NH}_{2}$ phenol & 13 & 76 & 14 & 70 & 75 & 68 & 80 & 62 & 50 & 76 & 50 & 72 & 200 & 74 & 220 & 65 \\
\hline 18 & $\begin{array}{l}\text { m-Chloro } \\
\text { aniline }\end{array}$ & 15 & 68 & 16 & 62 & 75 & 64 & 80 & 58 & 50 & 66 & 50 & 60 & 250 & 66 & 250 & 62 \\
\hline 19 & p-Toluidine & 14 & 75 & 15 & 70 & 75 & 65 & 80 & 60 & 50 & 76 & 50 & 68 & 200 & 72 & 220 & 60 \\
\hline 20 & o-Toluidine & 14 & 76 & 15 & 72 & 75 & 66 & 80 & 60 & 50 & 78 & 50 & 70 & 200 & 74 & 220 & 64 \\
\hline
\end{tabular}

VHR $=\left(\mathrm{DMF}+\mathrm{POCl}_{3}\right) ;$ SOLVENT $=$ Acetonitrile. 
strate that the obtained yields are good to excellent; the $\left(\mathrm{POCl}_{3}+\mathrm{DMF}\right) /\left(\mathrm{KNO}_{3}\right.$ or $\left.\mathrm{NaNO}_{2}\right)$ system afforded relatively better yields than the $\left(\mathrm{SOCl}_{2}+\mathrm{DMF}\right) /\left(\mathrm{KNO}_{3}\right.$ or $\mathrm{NaNO}_{2}$ ) system. This may be because the active electrophile $\left(\mathrm{NO}_{2}^{+}\right)$is released faster in the case of the $\left(\mathrm{POCl}_{3}{ }^{+}\right.$ $\mathrm{DMF}) /\left(\mathrm{KNO}_{3}\right.$ or $\left.\mathrm{NaNO}_{2}\right)$ system and is available for favorable Nitration over the $\left(\mathrm{SOCl}_{2}+\mathrm{DMF}\right) /\left(\mathrm{KNO}_{3}\right.$ or $\mathrm{NaNO}_{2}$ ) system. It is interesting to note that the reaction times under thermal conditions are too long even though the yields are fairly appreciative. However, the reaction times decreased substantially from several (14 to 15) hours to few minutes under solvent-free (mortar-pestle) grinding conditions followed by a fairly good increase in the prouct yield. This observation could be attributed to an increase in the fraction of activated species supplemented by the heat energy generated due to the friction in grinding process [23-26]. By and large similar rate enhancements were observed in the case of ultrasonically assisted reactions. The observed rate accelerations could be explained due to cavitation, a physical process that creates, enlarges, and implodes gaseous and vaporous cavities in an ultrasonically assisted (irradiated) liquid. Cavitation induces very high local temperatures in the reaction mixture and enhances mass transfer [33-35]. On the other hand in microwave irradiated reactions, the reaction times further reduced dramatically to only few seconds. The yields also enhanced from good to excellent showing the catalytic effect of non-conventional energy to activate the reactive species in this study. The observations are in accordance with the literature reports that the chemical reactions are accelerated because of selective absorption of microwave energy by polar molecules, nonpolar molecules being inert to the MW dielectric loss $[27,28]$.

\section{Conclusions}

In summary, the authors developed a protocol for imi- nium Salt Vilsmeier-Haack Reagent (VHR) triggered aromatic irradiated, sonicated and mortar-pestle) not only reduced the reaction times but enhanced the yield of products from good to excellent. The present finding is more advantageous because the reactions are conducted with economically cheap and readily available reagents. The reactions occur under mild and under environmentally safe conditions with a simple work up at room temperature.

\section{Experimental Details}

\subsection{General Procedure for Preparation of Vilsmeier-Haack Reagent}

The Vilsmeier Haack (VH) adduct is prepared afresh be- fore use from Oxychloride $\left(\mathrm{POCl}_{3}\right.$ or $\left.\mathrm{SOCl}_{2}\right)$ and dimethyl formamide (DMF). To a chilled (at $-5^{\circ} \mathrm{C}$ ) Oxychloride in acetonitrile (MeCN), calculated amount of dimethyl formamide (DMF) was slowly added drop wise, which resulted in slurry indicating the formation of $\mathrm{VH}$ reagent. The reagent thus obtained is stored under cold conditions.

\subsection{General Procedure for Synthesis of Nitro Arenes under Solvent Phase Conditions Using VH Reagent (Thermal)}

A centi molar $(0.01 \mathrm{~mol})$ organic substrate, (phenols, anilines), 0.01 moles of $\mathrm{KNO}_{3}$ or $\mathrm{NaNO}_{2}$ and about 0.015 moles of $\mathrm{VH}$ reagent and solvent (MeCN) were taken in a previously cleaned in a Round bottom flask and stirred for about 12 to 15 hours at room temperature. After completion of the reaction, as confirmed by TLC, the reaction mixture is treated with $5 \%$ sodium thiosulphate solution, followed by the addition of ethyl acetate. The organic layer was separated, dried over $\mathrm{Na}_{2} \mathrm{SO}_{4}$ and evaporated under vacuum, purified with column chromatography using pet-ether and ethyl acetate to get pure product.

\subsection{General Procedure for Synthesis of Nitro Arenes under Solvent Phase Conditions Using VH Reagent (Sonication)}

A centi molar (0.01 mol) organic substrate, (phenols, anilines), 0.01 moles of $\mathrm{KNO}_{3}$ or $\mathrm{NaNO}_{2}$ and about 0.015 moles of $\mathrm{VH}$ reagent and solvent (MeCN) were taken in a previously cleaned in conical flask at room temperature. After completion of the reaction, as confirmed by TLC, the reaction mixture is further processed for isolation of product as detailed in earlier section.

\subsection{General Procedure for Synthesis of Nitro Arenes under Solvent Free Conditions Using VH Reagent (Grinding)}

A centi molar $(0.01 \mathrm{~mol})$ organic substrate, (phenols, anilines), 0.01 moles of $\mathrm{KNO}_{3}$ or $\mathrm{NaNO}_{2}$ and about 0.015 moles of VH reagent in a previously cleaned in mortar grounded with a pestle. After completion of the reaction, as confirmed by TLC, the reaction mixture is further processed according to the above procedure to get pure product.

\subsection{General Procedure for Microwave Assisted Vilsmeier-Haack Synthesis of Nitro Arenes under Solvent Free Conditions}

A centimolar $(0.01 \mathrm{~mol})$ organic substrate (phenols, ani- 
lines), 0.01 moles of $\mathrm{KNO}_{3}$ or $\mathrm{NaNO}_{2}$ and about 0.015 moles of $\mathrm{VH}$ reagent were taken in a previously cleaned $50 \mathrm{ml}$ beaker. About $500 \mathrm{mg}$ of silica gel were added to the contents and mixed thoroughly and placed in microwave oven (CEM-908010, bench mate model, 300W laboratory microwave reactor). After completion of the reaction, as checked by TLC, the reaction mixture is treated with $5 \%$ sodium thiosulphate solution, followed by the same procedure as detailed above to get pure product.

\section{References}

[1] G. A. Olah, R. Malhotra and S. C. Narang, "Nitration Methods and Mechanisms,” VCH, New York, 1989.

[2] J. G. Hoggett, R. B. Monodie, J. R. Penton and K. Schofield, "Nitration and Aromatic Reactivity," Cambridge University Press, London, 1971.

[3] N. Ono, "The Nitro Group in Organic Synthesis,” WileyVCH, New York, 2001.

[4] G. K. Surya Prakash and T. Mathew, "Ipso-Nitration of Arenes," Angewandte Chemie International Edition, Vol. 49, No. 10, 2010, pp. 1726-1728.

[5] A. Kogelbauer, D. Vassena, R. Prins and J. N Armor, "Solid Acids as Substitutes for Sulfuric Acid in the Liquid Phase Nitration of Toluene to Nitrotoluene and Dini Trotoluene,” Catalysis Today, Vol. 55, No. 1-2, 2000, pp. 151-160.

[6] J. M. Riego, Z. Sedin, J. M. Zaldivar, N. C. Marziano and C. Tortato, "Sulfuric Acid on Silica-Gel: An Inexpensive Catalyst for Aromatic Nitration," Tetrahedron Letters, Vol. 37, 1996, pp. 513-516. doi:10.1016/0040-4039(95)02174-4

[7] X. Peng, H. Suzuki and C. Lu, "Zeolite-Assisted Nitration of Neat Toluene and Chlorobenzene with a Nitrogen Dioxide/Molecular Oxygen System. Remarkable Enhancement of Para-Selectivity," Tetrahedron Letters, Vol. 42, 2001, pp. 4357-4359. doi:10.1016/S0040-4039(01)00750-X

[8] S. P. Dagade, S. B. Waghmode, V. S. Kadam and M. K. Dongare, "Vapor Phase Nitration of Toluene Using Dilute Nitric Acid and Molecular Modeling Studies over Beta Zeolite," Applied Catalysis A, Vol. 226, No. 1-2, 2002, pp. 49-61.

[9] R. B. Radoslaw and J. S. Andrew, "A Fast and Mild Method for the Nitration of Aromatic Rings," Tetrahedron Letters, Vol. 42, No. 38, 2001, pp. 6767-6769. doi:10.1016/S0040-4039(01)01378-8

[10] N. Iranpoor, H. Firouzabadi, R. Heydari, “Silica-Polyethyleneglycols $/ \mathrm{N}_{2} \mathrm{O}_{4}$ Complexes as Heterogeneous Nitrating and Nitrosating Agents," Phosphorus, Sulfur and Silicon, Vol. 178, No. 5, 2003, pp. 1027-1035. doi:10.1080/10426500307863

[11] J. A. R. Rodrigues, A. P. Oliveira Filho, P. J. S. Moran and R. Custodio, "Regioselectivity of the Nitration of Phenol by Acetyl Nitrate Adsorbed On Silica Gel,” Tet- rahedron, Vol.55, No. 22, 1999, pp. 6733-6738. doi:10.1016/S0040-4020(99)00320-8

[12] J. A. R. Rodrigues, A. P. Oliveira Filho, P. J. S. Moran and R. Custodio, "Regioselectivity of the Mononitration of Alkylbenzenes by Immobilized Acyl Nitrates," Synthetic Communications, Vol. 29, No. 12, 1999, pp. 21692174. doi:10.1080/00397919908086213

[13] L. Delaude, P. Laszlo and K. Smith, "Heightened Selectivity in Aromatic Nitrations and Chlorinations by the Use of Solid Supports and Catalysts," Accounts of Chemical Re-search, Vol. 26, No. 12, 1993, pp. 607-613. doi:10.1021/ar00036a001

[14] P. Laszlo, "Catalysis of Organic Reactions by Inorganic Solids," Accounts of Chemical Research, Vol. 19, No. 4, 1986, pp. 121-127. doi:10.1021/ar00124a004

[15] A. R. Hajipour and A. E. Ruoho, "A Fast and Mild Method for Nitration of Aromatic Rings,” Phosphorus, Sulfur, and Silicon and the Related Elements, Vol. 179, No. 2, 2004, pp. 221-226. doi:10.1080/10426500490274655

[16] J. J. Paul Selvam, V. Suresh, K. Rajesh, S. Ravinder Reddy and Y. Venkateswarlu, "Highly Efficient Nitration of Phenolic Compounds by Zirconyl Nitrate," Tetrahedron Letters, Vol. 47, No. 15, 2006, pp. 2507-2509. doi:10.1016/j.tetlet.2006.02.057

[17] H. Firouzabadi, N. Iranpoor and M. A. Zolfigol, “A Reinvestigation of Nitration of Phenols with Metal Nitrates under Non-Aqueous and Aprotic Conditions," Iranian Journal of Chemistry and Chemical Engineering, Vol. 16, No. 2, 1997, pp. 48-58.

[18] M. M. Ali, Tasneem, K. C. Rajanna, P. K. Saiprakash, "An Efficient and Facile Synthesis of 2-Chloro-3-formylquinolines from Acetanilides in Micellar Media by Vilsmeier-Haack Cyclization,” Synlett, Vol. 32, No. 22, 2001, pp. 251-253.

[19] Tasneem, “Vilsmeier-Haack Reagent,” Synlett, Vol. 138139, No. 1, 2003, pp. 138-139.

[20] A. Chakradhar, R. Roopa, K. C. Rajanna and P. K. Saiprakash, "Vilsmeier-Haack Bromination of Aromatic Compounds with $\mathrm{KBr}$ and N-Bromosuccinimide Under Solvent-Free Conditions,” Synthetic Communications, Vol. 39, No. 10, 2009, pp. 1817-1824.

[21] S. Ramgopal, K. Ramesh, N. Maasi Reddy, A. Chakradhar and K. C. Rajanna, "Metal Nitrate Driven nitro Hunsdiecker Reaction with $\alpha, \beta$-Unsaturated Carboxylic Acids under Solvent-Free Conditions," Tetrahedron Letters, Vol. 48, No. 23, 2007, pp. 4043-4045. doi:10.1016/j.tetlet.2007.04.026

[22] K. C. Rajanna, N. Maasi Reddy, M. Rajender Reddy and P. K. Saiprakash, "Micellar Mediated Halodecarboxylation of $\alpha, \beta$-Unsaturated Aliphatic and Aromatic Carboxylic Acids-A Novel Green Hunsdiecker-Borodin Reaction,” Journal of Dispersion Science and Technology, Vol. 28, No. 4, 2007, pp. 613-616. doi:10.1080/01932690701282690

[23] G. R. Desiraju and B. S. Goud, "Reactivity of Solids. Present, Past, and Future,” V. V. Boldyrev, Ed., Blackwell Sciences, London, 1995, p. 223. 
[24] F. Toda, "Solid State Organic Reactions," Synlett, No. 5, 1993, pp. 303-312. doi:10.1021/ar00060a003

[25] K. Tanaka and F. Toda, "Solvent-Free Organic Synthesis," Chemical Reviews, Vol. 100, No. 3, 2000, pp. 10251074.

[26] J. D. Lou and Z. N. Xu, "Selective Oxidation of Primary Alcohols with Chromium Trioxide under Solvent Free Conditions," Tetrahedron Letters, Vol. 43, No. 35, 2002, pp. 6095-6097. doi:10.1016/S0040-4039(02)01333-3

[27] R. S. Varma, "Microwaves: Theory and Application in Material Processing IV,” D. E. Clark, W. H. Sutton and D. A. Lewis, Eds., American Ceramic Society, Westerville, Ohio, 1997, p. 357.

[28] J. Hamelin, J. P. Bazureau, F. Texier-Boullet and A. Louby, "Microwave in Organic Synthesis," Wiley-VCH, Weinheim, 2002, p. 253.

[29] A. Vilsmeier and A. Haack, "Über die Einwirkung von Halogenphosphor auf Alkyl-formanilide. Eine neue Methode zur Darstellung Sekundärer und Tertiärer p-Alkylamino-benzaldehyde" Berichte der Deutschen Chemischen Gesellschaft (A and B Series), Vol. 60, No. 1, 1927, pp. 119-122. doi:10.1002/cber.19270600118

[30] W. Su, Y. Weng, L. Jiang, Y. Yang, L. Zhao, Z. Chen and Z. Li, "Recent Progress in the Use of Vilsmeier-Type
Reagents," Organic Preparations and Procedures International, Vol. 42, No. 6, 2010, pp. 503-555. doi:10.1080/00304948.2010.513911

[31] I. M. A. Awad, "Studies on the Vilsmeier-Haack Reaction. Part XIII: Novel Heterocyclo-Substituted 4,4'-Bi-pyrazolyl Dithiocarbamate Derivatives," Chemical Technology and Biotechnology, Vol. 56, No. 4, 1992, pp. 339-345. doi:10.1002/jctb.280560403

[32] I. M. A. Awad, "Studies in the Vilsmeier-Haack Reaction, Part VII: Synthesis and Reaction of 3-Methyl-l-phenyl-4acetyl Hydrazono 2-Pyrazoline-5-one(-5-thione),” Monatshefte für Chemie, Vol. 121, No. 12, 1990, pp. 1023-1030

[33] T. J. Mason and J. P. Lorimer, "Sono Chemistry Theory, Applications and Uses of Ultrasound in Chemistry,” Ellis Horwood, New York, 1989.

[34] T. J. Mason, “Chemistry with Ultrasound," Critical Reports in Applied Chemistry, No. 28, 1990.

[35] M. H. Entezari and A. A. Shameli, "Shameli, Phase-Transfer Catalysis and Ultrasonic Waves I. Cannizzaro Reaction," Ultrasonics Sonochemistry, Vol. 7, No. 4, 2000, pp. 169-172. doi:10.1016/S1350-4177(00)00037-7 